\title{
Genetic Stability The Protein Encoding Envelope (E) Genes Dengue Virus Serotype-4 Passaged in Vero Cell As A Candidate Chimera Vaccine Material
}

\author{
Deya Karsari ${ }^{1,3 *}$, Fedik A. Rantam², Rahaju Ernawati², Eryk \\ Hendrianto ${ }^{3}$ \\ ${ }^{1}$ Vaccineology and Immunotherapeutics, Faculty of Veterinary Medicine, Universitas \\ Airlangga, Surabaya, Indonesia. \\ ${ }^{2}$ Department of Veterinary Microbiology, Faculty of Veterinary Medicine, Universitas \\ Airlangga, Surabaya, Indonesia. \\ ${ }^{3}$ Stem Cell Research and Development Center, Universitas Airlangga, Surabaya, \\ Indonesia. \\ *Corresponding author: deyaka88@gmail.com
}

\begin{abstract}
This study aims to analyze genetic stability of the gene encoding the envelope protein (E) dengue virus serotype-4 passaged in vero cells, Denv-4 passaged in vero cells serially then continued with RNA extraction at passage $0,10,20,30,40,50$, and 60, and then continued with two step PCR and amplification, and sequencing then analyze the nucleotide stability with BLAST and MEGA 5 software. The result shows that there are many variable site in nucleotide and amino acid with high mutation rate $57.4 \%$ for nucleotide and $71.9 \%$ for amino acid, while the similarity between passages are high ranging from $91 \%-98 \%$. The conclusion for this study is Denv-4 after analyzed shows that the gene encoding protein E has many variable site but high in similarity.
\end{abstract}

Key words: Dengue virus serotype-4, envelope, passage, stability

\section{INTRODUCTION}

Dengue virus has become one of the viruses that receive high attention in the world because of the lack of a licensed vaccine that can provide protection against all four dengue virus serotypes (WHO, 2009). Dengue virus is spread by Aedes species mosquitoes (A. aegypti and A. albopictus) in tropical and subtropical areas, the dengue virus is included in the genus Flavivirus which has four serotypes, namely Denv-1, Denv-2, Denv-3, and Denv-4, which are singlestranded positive RNA genomes (Coller et al., 2011, Mantel et al., 2011). Cases of disease caused by Denv-4 are described as sylvatic genotypes, namely dengue viruses that circulate exclusively in non-human primates and can be transmitted by Aedes mosquitoes and in majority cases of dengue hemorrhagic fever are caused by secondary infection of Denv-4 (Klungthong et al. al., 2004).

The wild strain virus type has been successfully patented through several passages in primaries dog kidney cells and monkey kidney cells (Chi-Lee et al., 2012). The biggest challenge in developing live-attenuated vaccines is evaluating the genomic stability of the new 
vaccines to ensure that the genomic heterogeneity produced by replication does not affect the stability of viral attenuation (Kenney et al., 2011). Protein E mediates the main biological activity that plays a major role in viral infectivity, in addition to several neutralizing epitopes that induce protective antibodies that are also present in protein $\mathrm{E}$, therefore protein $\mathrm{E}$ is an antigen that has received high attention in the dengue vaccine

\section{MATERIALS AND METHODS}

\section{Research Type and Research Design}

This research is a laboratory experimental study with a time series research design. Analyzing the genetic stability of the envelope protein coding gene (E) Denv- 4 of the University of Research Samples

Virus samples were selected ITD Denv-4 isolates from various regions in Indonesia and had been identified and attached to vero cells, Research Variables

The definitions of the variables in this study are as follows: Independent variable: passage. Dependent variables: nucleotide arrangement, Primary Design

The primers used in this study were primers designed by the Dengue Institute of Tropical Disease team, Airlangga University based on data from GenBank GQ398256.1, complete development strategy (Coller, 2011 ; Kuhn et al., 2002).

This study was designed to improve the chimera vaccine based on protein $\mathrm{E}$ for a vaccine model that is able to induce cellular and humoral immune responses for a long time without interference, reactogenicity, high safety based on Indonesian local isolates.
Airlangga Institute of Tropical Disease (ITD) isolate paired on vero cells based on the arrangement of nucleotides, amino acids, between passages-0, 10, 20, 30, 40, 50, and 60 .

using systematic sampling techniques aimed at $0,10,20,30,40,50$, and 60 passages.

amino acid composition. Control variables: vero cell culture, temperature, $\mathrm{CO} 2$ incubator

genome at positions 939 - 2423 based on the genomic map for dengue virus 4 by Kuiken and Turmond, (2005) such as in Appendix 3, FBSO, Citrogen technologies Pte. Ltd. Singapore.

Table 1. Specific Forward and Reverse primers for E Denv-4 protein

\begin{tabular}{|l|l|}
\hline Kode & Sequence \\
\hline FDen4/Env & $5^{\prime}$-AGGAGCAGACACATCAGAAG -3' \\
\hline RDen4/Env & $5^{\prime}$-TTGCACCTCTGTATGTGGAC $-3^{\prime}$ \\
\hline
\end{tabular}




\section{RNA extraction}

The vero cell culture that had been inoculated with Denv-4 was a coded dish culture blind passage (BP) $0,10,20,30,40,50$, and 60 each added trizole $1000 \mu \mathrm{l}$ for lysis of cells and resuspended, then put into a microtube then 200 $\mu \mathrm{l}$ of chloroform was added, shake for homogenization and incubated at room temperature for 5 minutes. Centrifugation at $12,000 \mathrm{rpm}, 15$ minutes, at $4^{\circ} \mathrm{C}$. Aquaface was taken and put into a new $1.5 \mathrm{ml}$ microtube and $500 \mu \mathrm{l}$ of isopropanol was added, for RNA

\section{cDNA SYNTHESIS}

Reverse Transcriptase Polymerase Chain Reaction was carried out in two steps using invitrogen's Thermoscript reagent. The first was to make a master mix, for one reaction in a sterile $0.5 \mathrm{ml}$ microcentrifuge tube, mix $7 \mu \mathrm{l}$ of NFW; 2 $\mu \mathrm{l} 10 \mathrm{mM}$ dNTP Mix; $2 \mu \mathrm{l}$ of RNA; and $1 \mu \mathrm{l}$ of Env reverse primer. Denv-4 (containing 20 pmol ( $\mu \mathrm{l})$, then incubated in a thermal cycler at a temperature of $65^{\circ} \mathrm{C}$ for 5 minutes, after

\section{PCR amplification}

PCR amplification was done by making master mix in a sterile $0.5 \mathrm{ml}$ microcentrifuge tube with a component of $2 \mu 1$ 10X PCR buffer minus $\mathrm{Mg}$ ++; $0.6 \mu 150$ mM MgCl2; $0.4 \mu 110$ mM dNTP mix, $0.5 \mu$ l of forward Env primers. Denv-4; 0.5 $\mu 1$ of Env reverse primer. Denv-4; $2 \mu \mathrm{cDNA}$ template; $0.2 \mu 1$ Taq DNA Polymerase; and 13.8

\section{Electrophoresis}

A total of $4 \mu 1$ of PCR results and $1 \mu 1$ of Blue Juice were added to $1 \%$ LE agarose well precipitation, shake and incubated at room temperature for 10 minutes. Centrifuged at a speed of $12,000 \mathrm{rpm}, 10$ minutes, at $4{ }^{\circ} \mathrm{C}$, then discard the supernatant carefully so that the pellets are not wasted and washed with $1000 \mu \mathrm{l}$ of $75 \%$ ethanol each. Centrifugation was performed again at a speed of 9,100 rpm, 7 minutes at $4^{\circ} \mathrm{C}$, discarded the supernatant and then let it air dry on laminar flow, then added $10 \mu \mathrm{l}$ of nuclease free water and piped for homogenization followed by RT-PCR for cDNA synthesis.

incubating place it on ice for 5 minutes, and adding a second master mix consisting of $2 \mu 1$ NFW; $4 \mu \mathrm{l}$ 5xcDNA Synthesis Buffer; $1 \mu 10.1$ DTT; $0.5 \mu \mathrm{l}$ RNase OUT (40 U / $\mu \mathrm{l}$ ); and $0.5 \mu \mathrm{l}$ of Thermoscript, incubated in a thermal cycler at $50{ }^{\circ} \mathrm{C}$ for 45 minutes and followed by a temperature of $85^{\circ} \mathrm{C}$ for 5 minutes, then added with $1 \mu \mathrm{l}$ of RNase $\mathrm{H}$ and incubated at $37^{\circ} \mathrm{C}$ for 20 minutes.

$\mu 1$ of NFW for a total of $20 \mu 1$. Incubate the tube in a thermal cycler with a Lid setting of $95^{\circ} \mathrm{C}$, predenaturation $94^{\circ} \mathrm{C}, 10$ minutes; denaturation $94^{\circ} \mathrm{C}, 1$ minute; annealing $55^{\circ} \mathrm{C}, 1$ minute; extention $72^{\circ} \mathrm{C}, 2$ minutes; the cycle is repeated at the denaturation stage for 40 times; extention prolongation $72^{\circ} \mathrm{C}, 10$ minutes; and keep at $4^{\circ} \mathrm{C}$.

containing $1 \mu \mathrm{l} / 50 \mathrm{ml}$ Ethidium Bromide for running process. The marker used as a reference 
was a 100 bp DNA ladder consisting of 15 fragments between $100 \mathrm{bp}$ and 1,500 bp and an additional 2072 bp fragment. The plates were run under $100 \mathrm{~V}, 400 \mathrm{~mA}$ conditions in 30-45

\section{SEQUENCING}

Sequencing is carried out in several stages, the first is purification of PCR products with QIAquick Gel Extraction Kit then labeled with Big Dye Terminator and loading on the sequencing machine This reaction is based on

\section{RESULT AND DISCUSSION}

The results of the electrophoresis of the E Denv4 protein coding gene isolate ITD passages 10 , $20,30,40,50$, and 60 using $1 \%$ agarose gel and minutes. Then the electrophoretic gel was read on the Gel Documentation / Transluminator UVP and documented.

fluorescent labeled material which will give the appropriate color change after passing the laser light on the automatic machine ABI PrismTM 310 Genetic analyzer Perkin Elmer.

100 bp DNA ladder as markers can see that the ribbon is parallel to the marker standard at the 562 bp position.

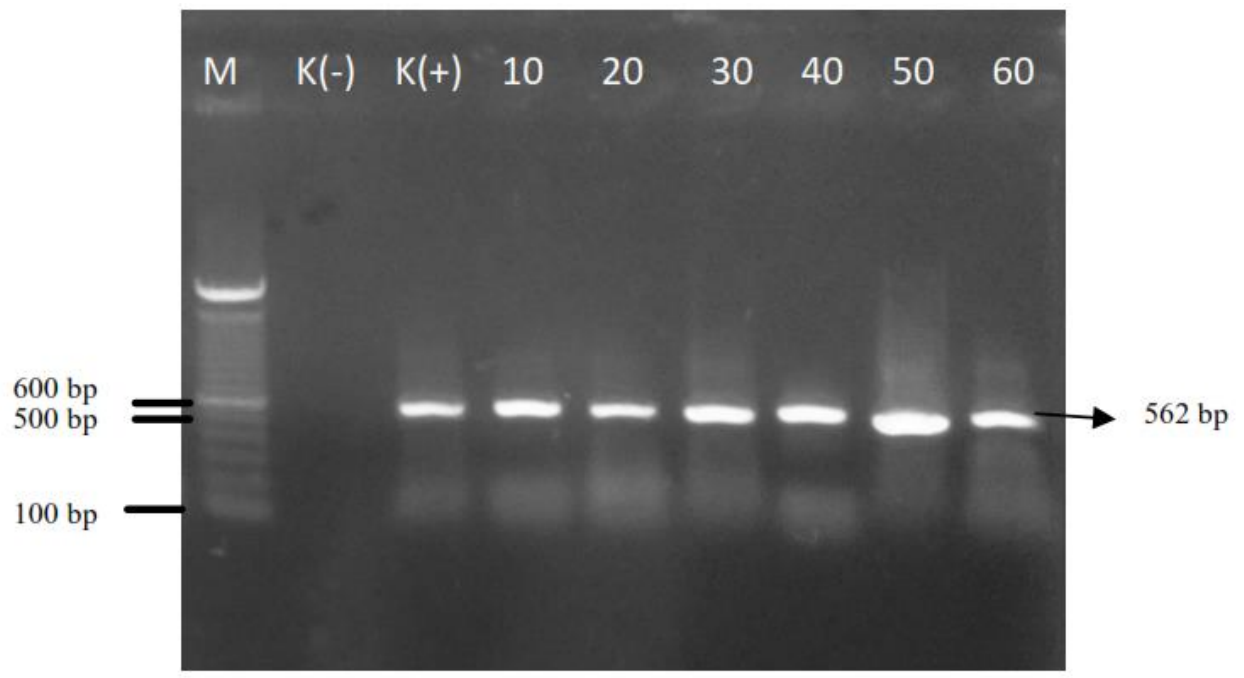

Figure 1 Denv-4 Electrophoresis Results

Note: $\mathrm{M}=$ Marker, $\mathrm{K}(-)=$ negative control, $\mathrm{K}(+)=$ positive control 
D4 Env bp 00 D4 Env bp-10. D4 ${ }^{-}$Env bp 20 D4 Env bp 30 $\mathrm{D}^{-}{ }^{-} \mathrm{Env}{ }^{-} \mathrm{bp}-40$ D4 Env bp 50 . D4_Env_bp_60.

D4 Env bp 00 D4 Env bp 10 . ${ }^{-} 4^{-}{ }^{-}{ }^{-}$bp 20 . D4_Env_bp_30 D4 Env bp 40 . D4 Env bp 50 . D4_Env_bP_60.

D4 Env bp 00 D4 Env bp 10 . D4 ${ }^{-}$Env ${ }^{-}$bp 20 . D4 Env bp 30 D4 Env bp 40 . D4 Env- bp-50. D4 Env bp-60.

D4 Env bp 00 D4 Env bp 10 . D4 ${ }^{-}$Env ${ }^{-}$bp 20. $\mathrm{D} 4{ }^{-} \mathrm{Env}^{-} \mathrm{bp}-30$. D4 Env bp 40 D4 Env bp 50 . D4 Env bp 60 .

D4 Env bp 00 D4 Env bp 10 . D4 Env bp 20. D4 ${ }^{-}{ }^{-}{ }^{-}$bp -30 D4 Env bp_40. D4 Env bp 50 . D4 Env bp 60 .

D4 Env bp 00 D4 Env-bp-10. D4 Env bp 30 . D4 Env bp 40 . D4 Env bp 50 . D4_Env_bp_60.

D4 Env bp 00 D4 Env ${ }^{-}{ }^{-}-10$ D4 Env-bp-20. D4 Env- bp 30 . D4 Env_bp_30. D4 Env bp-50. D4 Env_bp_60.

D4 Env_bp_00 D4 Env ${ }^{-}$bp 10 . D4 Env-bp-20. D4 Env bp 30 . D4 Env_bp_40. D4 Env bP_60.

D4 Env bp_00 D4 Env bP-10. D4 Env bp 20 . D4 Env bp 30 . D4 Env bp 40 . D4 Env bp 50 . D4_Env_bp_60.
$10 \quad 20$ 30 40 50

AATCATAAAGAGAGATGGTGACGTCAAGGTCCTCATGCCAAGAGACAGGATGTGACA GC.T.C. .TAG.TGCA.GC. TGCT.GA..G. . A. . . . . . . . . . . . $\ldots$ T.C. . . . . . . . . . . . . . . . . . . . . $\ldots \ldots \ldots$

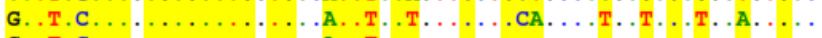

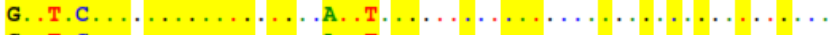

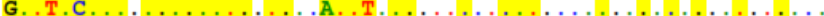

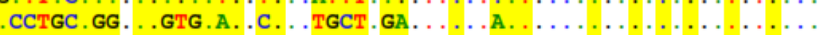

$\begin{array}{lllll}70 & 80 & 90 & 100 & 110\end{array}$ GTGCTAGGATCTCAGGAGGGAGCTATGCATTCTGCCCTCGCCGGAGCACAGAAGTGGAT

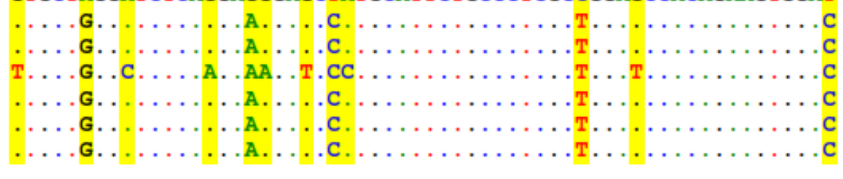

$\begin{array}{llllll}130 & 140 & 150 & 160 & 170 & 180\end{array}$ TCTGGTGATGGAATCACATGTTTGCAGGACATCTCAAGTGCAAAGTCCGATGGAGAA

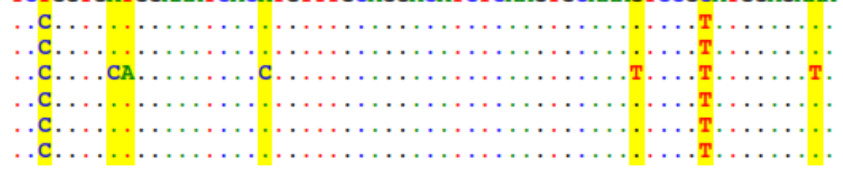

$\begin{array}{llll}190 & 200 \quad 210 & 220 & 230\end{array}$ TTGAGAATTAAAGGATGTCATACACGATGTGTTCAGGAAGTTCTCAATTGACAAAGA ........... . .

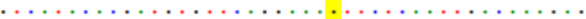

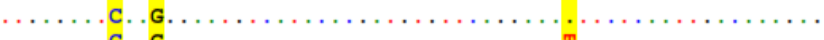

.......... . .

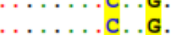

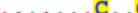

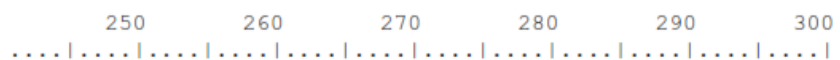

ATGGCAGAAACACAGCATGGAACAACAGTGGTGAAAGTCAAGTATGAAGGCG TGGAGCT

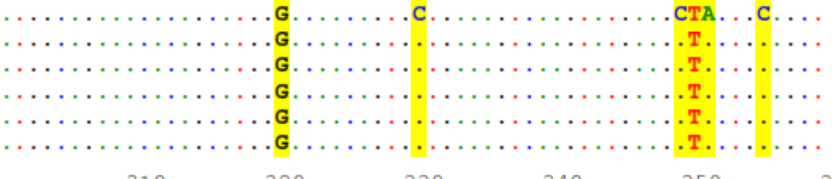
310
320
330
340
350
360

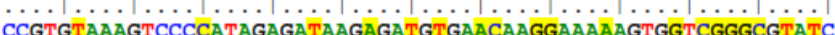

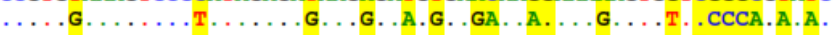
… . .

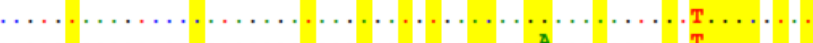

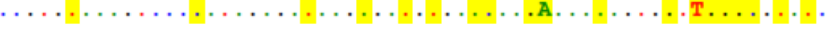

$\ldots \ldots|\ldots| \ldots|\ldots| \ldots|\ldots| \ldots|\ldots| \ldots|\ldots| \ldots|\ldots| \ldots|\ldots| \ldots \mid$

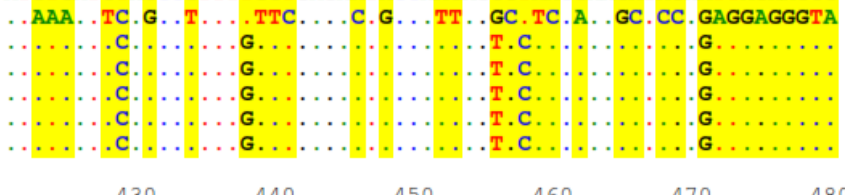
$\ldots \ldots|\ldots| \ldots|\ldots| \ldots|\ldots| \ldots|\ldots| \ldots|\ldots| \ldots|\ldots| \ldots|\ldots|$ ATA. CAAA.TTTC.T.C.T. . .C.C. .GA. .T.C.TTC. .G. .TTGT. .TT. . .

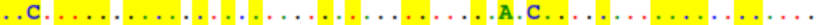

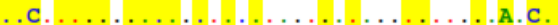

C.

.с. ...

490

510

520

530

$\ldots \ldots|\ldots| \ldots|\ldots| \ldots|\ldots| \ldots|\ldots| \ldots|\ldots| \ldots|\ldots|$

C. T. . .TG.CA.AT. . TG. . TT. .GA. .TC.G.G.AA.TT.GGT.AGTC

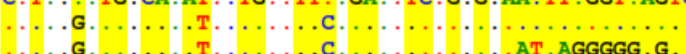

……

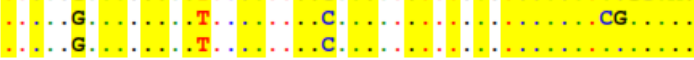

Figure 2 Analysis of the 0,10,20,30,40,50, and 60th passage of Denv-4 nucleotide strands. 
Variable sites from Bp 0 to $\mathrm{Bp} 10$ there are 117 variable sites (22\%), from Bp 0 to $\mathrm{Bp} 20$ there are 28 variable sites (5.3\%), from $\mathrm{Bp} 0$ to $\mathrm{Bp} 30$ there are 57 variable sites (10.8\%), from Bp 0 to $\mathrm{Bp} 40$ there are 31 variable sites $(5.8 \%)$, from $\mathrm{Bp} 0$ to Bp 50 there are 29 variable sites (5.4\%), from Bp 0 to $\mathrm{Bp} 60$ there are 43 variable sites $(8.1 \%)$.

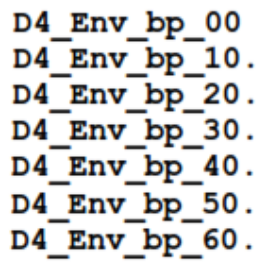

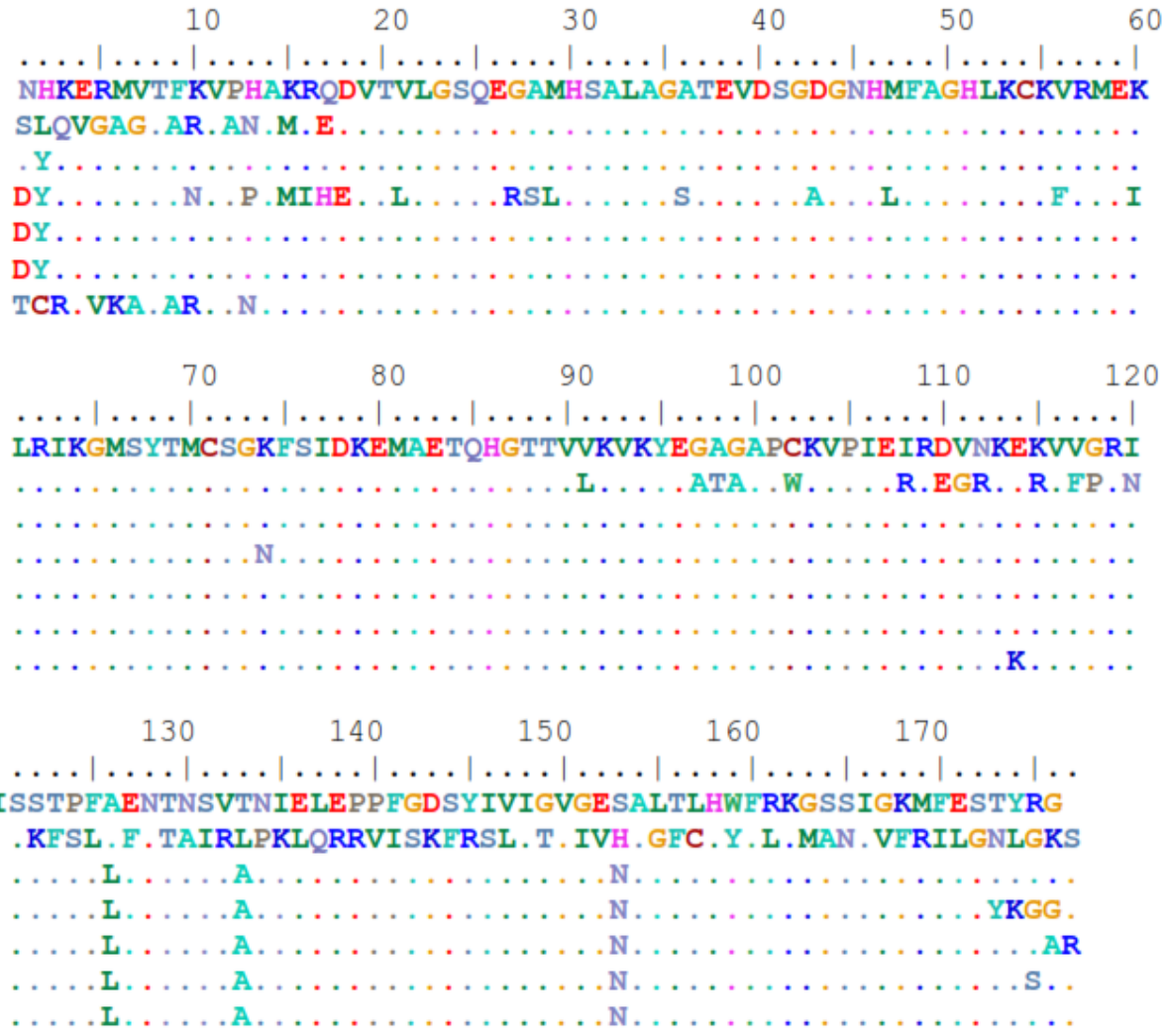

Figure 3 Denv-4 amino acid analysis of 0, 10,20,30,40,50, and 60 passages
Amino acid variable sites from $\mathrm{Bp} 0$ to $\mathrm{Bp} 10$ there are 74 variable sites (41\%), from Bp 0 to $\mathrm{Bp}$ 20 there are 4 variable sites $(2,3 \%)$, from Bp 0 to Bp 30 there are 25 variable sites (14\%), from Bp 0 to $\mathrm{Bp} 40$ there are 7 variable sites $(3,9 \%)$, from Bp 0 to Bp 50 there are 6 variable sites $(3,4 \%)$, from $\mathrm{Bp} 0$ to $\mathrm{Bp} 60$ there are 13 variable sites (7.3\%). RNA viruses can undergo mutations on average from $10-3$ to $10-5$ substitution per nucleotide copy or about $1 \%$ to $3 \%$. This allows for rapid adaptation and evolution when viral RNA is subjected to selective pressure changes. These mutations are the result of high frequency in diverse mutant populations of the viral genome (Liu et al., 2008; Nor et al., 2010). 
Table 2 BLAST Analysis of E Denv-4 Protein Coding Genes

\begin{tabular}{|c|c|c|c|c|c|c|}
\hline Description & $\underline{\text { Max score }}$ & $\underline{\text { Total score }}$ & Query cover & $\underline{\text { E value }}$ & $\underline{\text { Ident }}$ & Accession \\
\hline D4_Env_bp_10 & 422 & 422 & $60 \%$ & $2 \mathrm{e}-122$ & $91 \%$ & 41603 \\
\hline D4_Env_bp_20 & 824 & 824 & $98 \%$ & 0.0 & $95 \%$ & 51077 \\
\hline D4_Env_bp_30 & 695 & 695 & $96 \%$ & 0.0 & $91 \%$ & 2037 \\
\hline D4_Env_bp_40 & 821 & 821 & $97 \%$ & 0.0 & $95 \%$ & 45581 \\
\hline D4_Env_bp_50 & 819 & 819 & $98 \%$ & 0.0 & $95 \%$ & 46461 \\
\hline D4_Env_bp_60 & 785 & 785 & $94 \%$ & 0.0 & $95 \%$ & 50537 \\
\hline
\end{tabular}

Table 3 BLAST Analysis of Amino Acids for E Denv-4 Protein Coding Gene

\begin{tabular}{|c|c|c|c|c|c|c|}
\hline Description & $\underline{\text { Max score }}$ & $\underline{\underline{T o t a l} \text { score }}$ & $\underline{\text { Ouerv cover }}$ & $\underline{E \text { value }}$ & $\underline{\text { Ident }}$ & Accession \\
\hline D4_Env_bp_10 & 207 & 207 & $93 \%$ & $1 \mathrm{e}-72$ & $63 \%$ & 42027 \\
\hline D4_Env_bp_20 & 359 & 359 & $100 \%$ & $2 \mathrm{e}-132$ & $98 \%$ & 36447 \\
\hline D4_Env_bp_30 & 314 & 314 & $97 \%$ & $1 \mathrm{e}-114$ & $88 \%$ & 5783 \\
\hline D4_Env_bp_40 & 355 & 355 & $99 \%$ & $7 \mathrm{e}-131$ & $97 \%$ & 52625 \\
\hline D4_Env_bp_50 & 354 & 354 & $100 \%$ & $3 \mathrm{e}-130$ & $97 \%$ & 43173 \\
\hline D4_Env_bp_60 & 340 & 340 & $98 \%$ & $1 \mathrm{e}-124$ & $94 \%$ & 14715 \\
\hline
\end{tabular}

From Table 2, the closest similarity to BP 0 is BP 20, 40, 50, and 60, namely $95 \%$, while BP 10 and 30 have similarity to BP 0 only $91 \%$. Table 3 shows that BP 0 compared to BP 10 has only $63 \%$ similarity, BP 0 compared to BP 20 has 98\% similarity, BP 0 compared to BP 30 has a similarity of $88 \%$, BP 0 compared to Bp 40 has a similarity of $97 \%$, BP 0 compared to Bp 50 has a similarity of $97 \%$, BP 0 compared to BP 60 has a similarity of $94 \%$. From existing data, BP 0 compared to BP 20 has the highest similarity, namely $98 \%$ and the lowest is seen in the comparison of BP 0 with BP 10.

According to Sasmono et al (2012) the occurrence of changes in the composition of nucleotides can indicate the dynamics of the genetic characteristics of this virus because the virus is repeated in phase so that this virus adapts to cells by changing its genetic makeup. Chemical mutagenesis and analysis of Denv-4 sequencing results conducted by Blaney et al., 2001 have resulted in the identification of a large number of point mutations that result in amino acid substitution in all genes except Capsid and NS4A and point mutations in untraslated regions (UTRs). The mutations examined every few passages in vero cells, may be adaptive changes that give the Denv-4 increased efficiency of replication in vero cells. 


\section{CONCLUSION}

The nucleotide composition analysis had a high mutation rate of more than $3 \%$, especially in the 10th passage compared to the 0th passage, which was $22 \%$ and the one with the lowest mutation rate was the 20th passage, namely $5.3 \%$ and the average mutation rate $57.4 \%$. The analysis of amino acid composition has a high diversity of more than $3 \%$ because there are many site variables, especially in the 10th passage where the diversity reaches $41 \%$ while the lowest mutation rate is in the 20th passage of $2.3 \%$, and the average -the mutation rate average was $71.9 \%$.

\section{REFERENCES}

Blaney, J.E.Jr., G. G. Manipon, C.Y. Firestone, D. H. Johnson,C. T. Hanson, B. R. Murphy, S. S. Whitehead. 2003. Mutations Which Enhance The Replication of Dengue Virus Type 4 and An Antigenic Chimeric Dengue Virus Type 2/4 Vaccine Candidate in Vero cells. Vaccine 21: 4317-4327

Chi-Lee, H., M. Butler, S.C. Wu. 2012. Using recombinant DNA technology for the development of live-attenuated dengue vaccines. Enzyme and Microbial Technology 51: 67-72

Coller, B.A.G., D.E. Clements, A.J. Bett, S.L. Sagar, J.H.T. Meulen. 2011. The development of recombinant subunit envelope-based vaccines to protect
This research is a preliminary study in the development of the dengue chimera vaccine where the genetic stability of $\mathrm{E}$ protein which plays an important role in the formation of neutralizing antibodies needs further research, the results of this study are not as expected by researchers but that does not mean that Denv-4 is unstable, therefore more studies are needed. further, to find viral passages with nucleotide strands that have a stable conserved site as a candidate vaccine ingredient.

against dengue virus induced disease. Vaccine 29: 7267-7275

Kenney J. L., S. M. Volk, J. Pandya, E. Wang, X. Liang, and S. C. Weaver. 2011. Stability of RNA Virus Attenuation Approaches. National of Healh Public Access University of Texas. Vaccine 29: $2230-2234$

Klungthong, C., C.Zhang, M.P. Mammen Jr, S. Ubol and E.C. Holmes. 2004. The molecular epidemiology of dengue virus serotype 4 in Bangkok, Thailand. Virology 329:168-179

Kuiken, C. And J. Turmond. 2005. Genomic Map for Dengue Virus 4. HFV sequence data base. http://hfv.lanl.gov/cgibin/HFV/GenomeMapper 
Kuhn, R.J., W.Zhang, M.G.Rossman, S.V. Pletnev, J.Corver, E.Lenches, C.T., Jones, S.Mukhopadhyay, Chipman P.R. and Strauss J.H .2002. Structure of dengue virus: implications for flavivirus organization, maturation, and fusion. Cell. 108:717-725

Liu C.C., S.C. Lee, M. Butler, S.C. Wu. 2008. High Genetic Stability of Dengue Virus Propagated in MRC-5 Cells as Compared to the Virus Propagated in Vero Cells. Plosone Volume 3 , Issue 3, e1810.

Mantel N., Y. Girerd, C. Geny, I. Bernard, J. Pontvianne, J. Lang, V. Barban. 2011. Genetic Stability of a Dengue Vaccine Based on Chimeric Yellow Fever/Dengue Viruses. Vaccine 29: 6629- 6635
Nor Y. A., N. H. Sulong, M. Mel1, H. M. Salleh, I. Sopyan. 2010. The Growth Study of Vero Cells in Different Type of Microcarrier. Materials Sciences and Applications, 1: 261-266

Sasmono, T., B. Yohan, T.Y. Setianingsih, Aryati, P. Wardhani dan F.A. Rantam. 2012. Identifikasi Genotipe dan Karakterisasi Genome Virus Dengue di Indonesia untuk Penentuan Prototipe Virus Bahan pembuatan Vaksin Dengue Berbasis Strain Indonesia.

http://insentif.ristek.go.id/PROSIDING/ RD-2012-0422.htm

World Health Organization. Vector-borne viral infections: dengue fever [online]; 2009 http://www.who.int/vaccineresearch/dis eases/vector/en/index1.html. 